\title{
Chemical-mechanical polishing of sapphire by polishing suspension based on aerosil
}

\author{
E.A.Vovk \\ Institute for Single Crystals, STC "Institute for Single Crystals", National \\ Academy of Sciences of Ukraine, 60 Lenin Ave., 61001 Kharkiv, Ukraine
}

Received April 15, 2015

\begin{abstract}
The conditions for the optimal balance among the degree of agglomeration of aerosil in the polishing suspension, removal rate, and the quality of the polished sapphire surface under chemical-mechanical polishing (CMP) with the polishing suspension contained surfactants at different $\mathrm{pH}$ were determined. It was determined that these conditions depend on the crystallographic orientation of the sapphire surface. Surface roughness $R_{a}$ 0.2$0.4 \mathrm{~nm}$ and the optical quality class 20/10-40/20 (USA MIL O 13830) was obtained for orientations (0001), (1120), and (10T2) by CMP with the polishing suspension contained the surfactant with $\mathrm{OH}$ functional groups, and at optimal value of $\mathrm{pH}$ for each orienta-
\end{abstract} tions.

Keywords: sapphire, chemical-mechanical polishing, polishing suspension, silica, aerosil, deagglomeration.

\begin{abstract}
Установлены условия оптимального баланса между степенью агломерации аэросила в суспензии, скоростью съема и качеством полированной поверхности при химико-механическом полировании сапфира при использовании полировальной суспензии, содержащей поверхностно-активное вещество при разном рН. Определено, что эти условия зависят от кристаллографической ориентации поверхности сапфира. Для ориентаций (0001), (1120), (10Т2) получена поверхность с шероховатостью $R_{a} 0.2-0.4$ нм и оптическим качеством класса 20/10-40/20 (USA MIL-O-13830) при использовании полировальной суспензии, содержащей поверхностно-активное вещество с функциональными группами $\mathrm{OH}$, при оптимальном для каждой ориентации значении $\mathrm{pH}$.
\end{abstract}

Хіміко-механічне полірування сапфіра з використанням полірувальної суспензії на основі аеросилу. О.О.Вовк.

Встановлено умови оптимального балансу між ступенем агломерації аеросилу в суспензії, швидкістю знімання та якістю полірованої поверхні сапфіра при хіміко-механічному поліруванні при використанні полірувальної суспензії, що містить поверхнево-активну речовину при різному $\mathrm{pH}$. Визначено, що ці умови залежать від кристалографічної орієнтації поверхні сапфіра. Для орієнтацій (0001), (1120), (10Т2) одержано поверхню з шорсткістю $R_{a}$ 0.2-0.4 нм та оптичною якістю класу 20/10-40/20 (USA MIL-O-13830) при використанні полірувальної суспензії, яка містить поверхнево-активну речовину з функціональними групами $\mathrm{OH}$, при оптимальному для кожної орієнтації значенні $\mathrm{pH}$.

\section{Introduction}

Sapphire is one of the most common used substrate materials in the world [1,2]. Sapphire substrates are applied for the LED production, which rapidly developing around the world, and they are used traditionally for manufacturing integrated circuits based on epitaxial layers of silicon on sapphire. The high surface quality requirements of the substrates call improvement technologies of sapphire surface finishing, 
in particular chemical-mechanical polishing (CMP).

The most common CMP method of sapphire is burnished with polishing suspension comprised silica [3]. The polishing suspension should be a low-viscosity suspension of monodisperse particles of $\mathrm{SiO}_{2}$. Such suspensions supplied by industrial company Nalco are the most widely used to polish sapphire, silicon carbide semiconductors and other materials [4,5]. Nalco suspensions are too expensive, there are much cheaper suspensions contained silica in the form of aerosil (pyrogenic silica). However aerosil obtained by way of high-temperature synthesis is strongly agglomerated, and it forms agglomerates when mixed with water. The primary particle size of aerosil is ranged of 7 to $40 \mathrm{~nm}$, while suspension made from this aerosil comprises agglomerates of up to $10 \mu \mathrm{m}$. Presence of such large particles in the polishing suspension under burnish leads to formation of scratches and other defects on the sapphire surface. To break up the agglomerates and to stabilize the suspension applied the mechanical, chemical, and ultrasonic methods of exposure $[6,7]$. The effects of $\mathrm{pH}$, surface active agents (surfactants), and degree of dispersion of the ultrasonic on deagglomeration of aerosil in the polishing suspension, the removal rate of sapphire, and optical quality of polished surface were studied [8]. It was found that increasing $\mathrm{pH}$ reduce the agglomerate size, and sapphire removal rate increases and passes through a maximum at $\mathrm{pH} 8.4$ for all crystallographic planes. However, the quality of the surface during polishing remains unsatisfactory. At the same time addition to the suspension the surfactant of $0.2-1.3$ wt. $\%$, contained hydroxyl groups at $\mathrm{pH} 4.5$ caused increasing removal rate and the surface quality.

The purpose of this study is to establish conditions for the optimum balance among the degree of agglomeration of the aerosil in suspension, removal rate, and surface quality by means the polishing suspension contained the surfactant at different $\mathrm{pH}$ that will allow to develop the polishing suspension composition for CMP of sapphire based on aerosil, and to obtain the surface with high optical quality.

\section{Experimental}

CMP was performed on sapphire disks of $\varnothing 70 \times 3 \mathrm{~mm}^{2}$ with the crystallographic orientations of the surface (0001), (10T2) and (1120). We have previously found that the

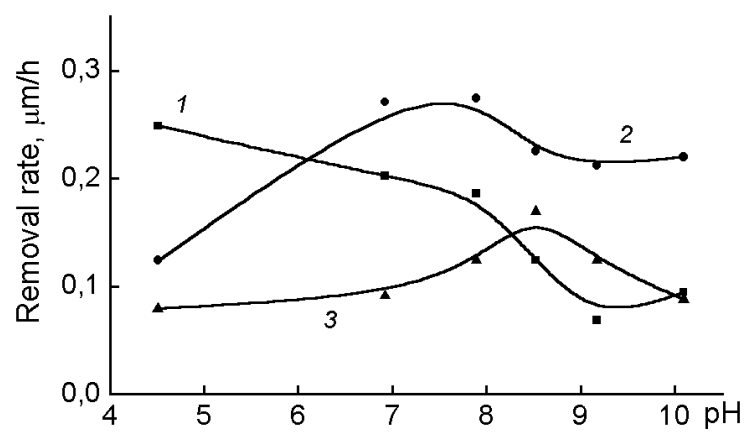

Fig. 1. Dependences of removal rate of sapphire with the crystallographic orientation of the surface: $1-(0001), 2-(10 T 2)$, and 3 - (1120) on $\mathrm{pH}$ of the polishing suspension contained surfactant.

process of obtaining the sapphire surface of high optical quality became more complicated with decreasing angle of deviation from the geometrical surface crystallographic plane [9]. Therefore, the study involves samples with an inclination angle not more than 0.3 ang.deg, which polishing are the most difficult. The samples were mechanically polished by means of the diamond paste ACM 28/20 and then subjected to CMP in aerosil suspension to remove the damaged layer completely. CMP was realized on a special faceplate, which allowed to treat simultaneously three samples under identical conditions. The rate of CMP quantitatively estimated based on removal rate of sapphire calculated from the loss of the sample mass according to the procedure described in detail in [9]. The polishing suspension was prepared from aerosil with specific surface $380 \mathrm{~m}^{2} / \mathrm{g}$ (Ukraine) and deionized water. The suspension comprises aerosil of 5 wt. $\%$, surfactants contained hydroxy groups of 1.3 wt.\%. $0.5 \mathrm{M}$ solution of $\mathrm{NaOH}$ was used to adjust $\mathrm{pH}$. The surfactant solution dropwised to the suspension under constant stirring. The suspension was homogenized by means of a mechanical mixer rotating at velosity of $1200 \mathrm{rpm}$ during two hours.

Suspension viscosity was measured by glass viscometer at $20^{\circ} \mathrm{C}$. Morphology of the aerosil particles was studied on transmission electron microscope (TEM) EM 125 with $100 \mathrm{kV}$ accelerating voltage. Both the morphology and surface roughness of the sapphire samples were studied with atomic force microscope (AFM) Solver P47H PRO (NT-MDT). Optical quality of the surface was estimated by optical microscope MBS-2. 

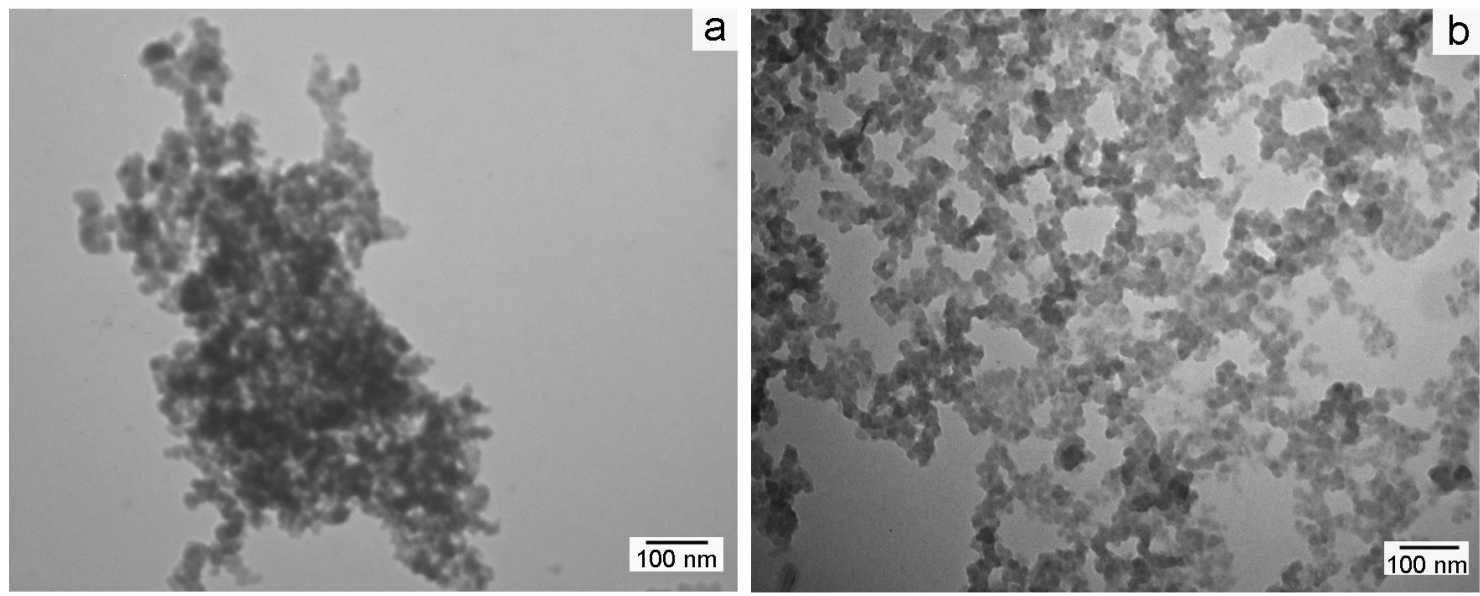

Fig. 2. TEM images of aerosil particles in the polishing suspension: (a) without surfactants, (b) with surfactant.

\section{Results and discussion}

Under the CMP by the polishing suspension contained surfactant the removal rate depends on $\mathrm{pH}$ for different crystallographic orientations of the sapphire surface in different way (Fig. 1). Decreasing the rate throughout the whole experimental range of $\mathrm{pH}$ was observed for crystallographic plane (0001). Whereas, for the planes (10T2) and (1120) the curves of these dependences show the maximum at $\mathrm{pH} 7-8$ and $\mathrm{pH} 8-9$, respectively. The removal rate for the plane $(1120)$ increases in 2.3 times while the $\mathrm{pH}$ value increases from 4.5 to 8 . Thus, there is own range of $\mathrm{pH}$ for the each crystallographic plane that the removal of material takes place most vigorously. This behavior of the removal rate differs from the CMP in suspension without surfactant, wherein the nature of dependences of removal rate on $\mathrm{pH}$ similar for all crystallographic orientations: with increasing $\mathrm{pH}$ the removal rate increases and passes through the maximum at $\mathrm{pH} 8.3$ [8]. It should be noted that the addition of the surfactant to the suspension causes increasing removal rate up to 1.5 times, which reduces the CMP time.

The viscosity of the polishing suspension increases from 2.12 to $4.30 \mathrm{cP}$ (at $\mathrm{pH} 4.5$ ) with addition of the surfactant of 0 to 1.3 wt. $\%$. Recently, in the study of morphology of the particles in the polishing suspension at $\mathrm{pH}$ of 4.5 we have found that the addition of surfactant occurred disaggregation of the aerosil particles [8]. In our case, there is increase in the viscosity, which indicates decrease in the mobility of the particles. The probable cause of increase in the viscosity of the suspension is flocculation, i.e. adhesion of the individual particles to each other in the presence of the surfactants. Fig. 2 shows morphology of the agglomerated particles in the aerosil suspension without surfactant, and flocculated ones in the presence of the surfactants. The flocculation mechanism is that the surfactant contained $\mathrm{OH}$ groups adsorb on the aerosil particles with forming the hydrogen bonding between the hydroxyl groups of the polymer molecule and $\mathrm{SiOH}$ groups on the aerosil surface. Since the length of the polymer molecules, much more than of the aerosil particles, one polymer molecule can be attached to two different particles of aerosil generated bridge bonds. The flocculation can also be resulted in clumping the hydrophobic parts of the surfactant molecules surrounding the different particles of aerosil [10].

The increase of the suspension $\mathrm{pH}$ cause the viscosity decrease, which at above $\mathrm{pH} 8$ is stabilized at the value of $\sim 2.3-2.5 \mathrm{cP}$ (Fig. 3). This is probably due to that the adsorption of the surfactant is maximal at the isoelectric point of aerosil ( $\mathrm{pH} \mathrm{2-3} \mathrm{[11])}$ and decreases with the $\mathrm{pH}$ increasing attributed to raise negative charge on the aerosilparticles surface. Thus, the presence of negative charge on the particle surface results in the particle deflocculation. The lowering viscosity improves the rheological properties of the suspension, and facilitates its mixing in the polishing bath.

The criteria for evaluating the CMP effectiveness are the high removal rate of sapphire, ability to achieve roughness in the range of $0.2-0.4 \mathrm{~nm}$, and high optical quality of the polished surface. In order to de- 


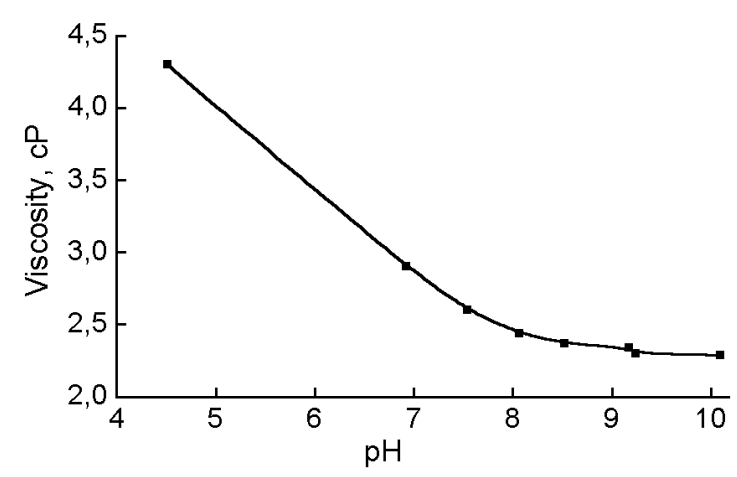

Fig. 3. Dependence of viscosity of the polishing suspension on $\mathrm{pH}$.

termine $\mathrm{pH}$ range of the suspension, which is optimal for polishing of each crystallographic sapphire plane, the removal rate was measured simultaneously with the surface roughness $R_{a}$ (Fig. 4). It was determined that for the sample with the orientation (0001) the roughness $R_{a} 0.2-0.4 \mathrm{~nm}$ is achieved throughout the whole $\mathrm{pH}$ range, and the removal rate at $\mathrm{pH} 4.5-7.5$ is highest. Consequently, for the orientation (0001) usage of the polishing suspension with $\mathrm{pH} 4.5-7.5$ is the most effective, for the plane (10T2) the most optimal polishing suspension possess $\mathrm{pH}$ 6.5-9.5, and for the plane $(1020)$ is better to use the suspension with $\mathrm{pH}$ 7.5-9.5. It was established that the surface roughness of all samples is homogeneous with tolerance measured in the center and in the periphery not more than $0.1 \mathrm{~nm}$.

The high optical quality of the all samples surface, which corresponded to optical cleanliness class 20/10 standard USA MIL O 13830, was achieved. Figure 5 shows the AFM image and surface profilograms of the samples with the crystallographic orientation of the surface (1012) and (0001). Scratches and other surface defects are no revealed. In the AFM image of sapphire orientation (0001) the terrace-step surface structure observed due to outcrops of oxygen sublattices of the sapphire crystal cell. Such a structure can be formed on the ultra-smooth vicinal crystal surface while the surface roughness is comparable in magnitude with the distance between adjacent sublattices $[12,13]$. Formation of the terraced-step structure on the surface (0001) confirms obtaining the surface roughness with value closed to the distance between the oxygen sublattice in the direction [0001]. Since the unit cell parameter of sapphire in [0001] is $c=1.300 \mathrm{~nm}$, therefore the minimum distance between the closepacked oxygen layers of sapphire will be
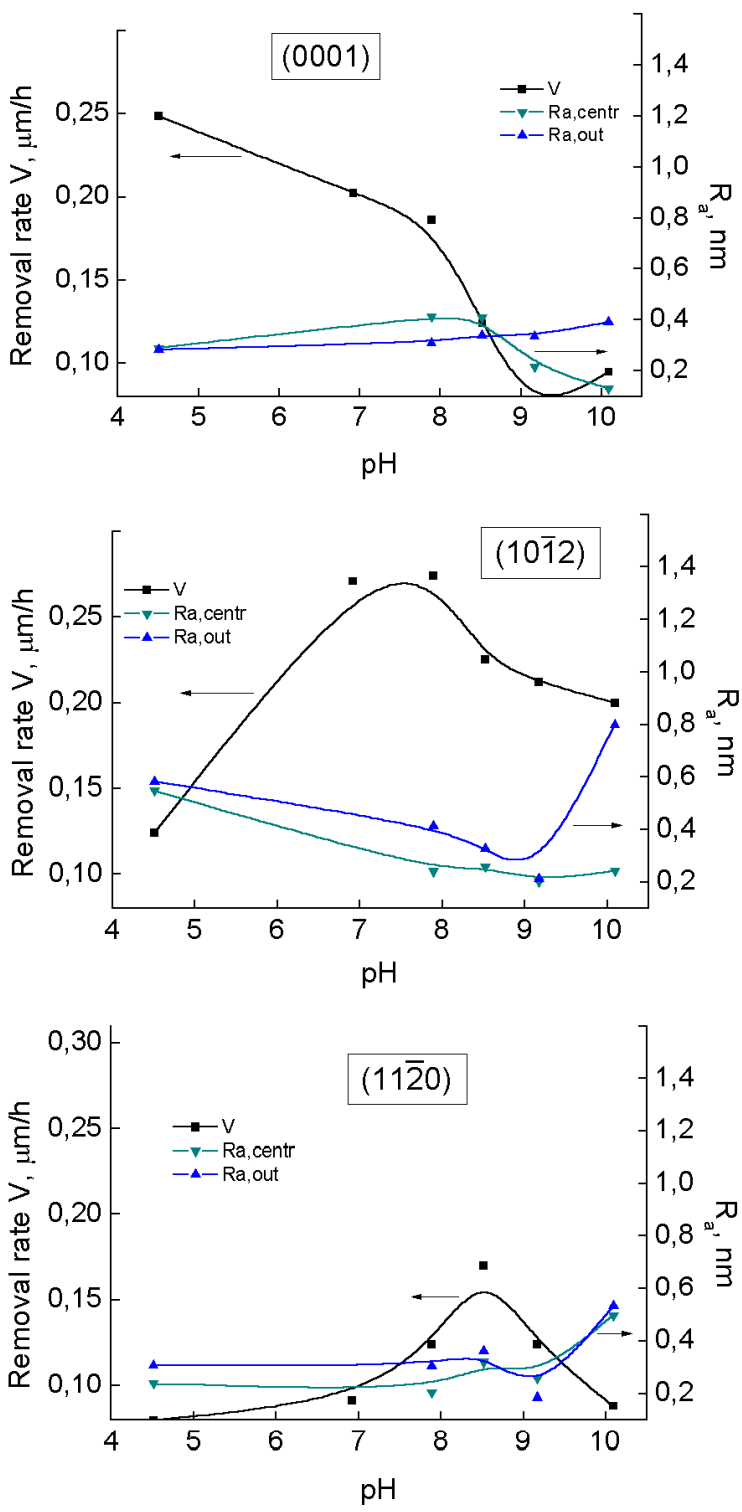

Fig. 4. Dependences of removal rate and roughness $R_{a}$ in the center and in the periphery of the sample after CMP on $\mathrm{pH}$ of the polishing suspension for different crystallographic orientations of the sapphire surface.

$c / 6=0.22 \mathrm{~nm}$, which is consistent with the results of the AFM (Fig. 5b).

\section{Conclusions}

The conditions for the optimum balance among the degree of agglomeration of aerosil in the polishing suspension, removal rate, and the quality of the polished sapphire surface under usage of the polishing suspension contained surfactants at different $\mathrm{pH}$ were determined. It was shown that, addition of surfactants with hydroxyl groups to the aqueous suspension of aerosil 

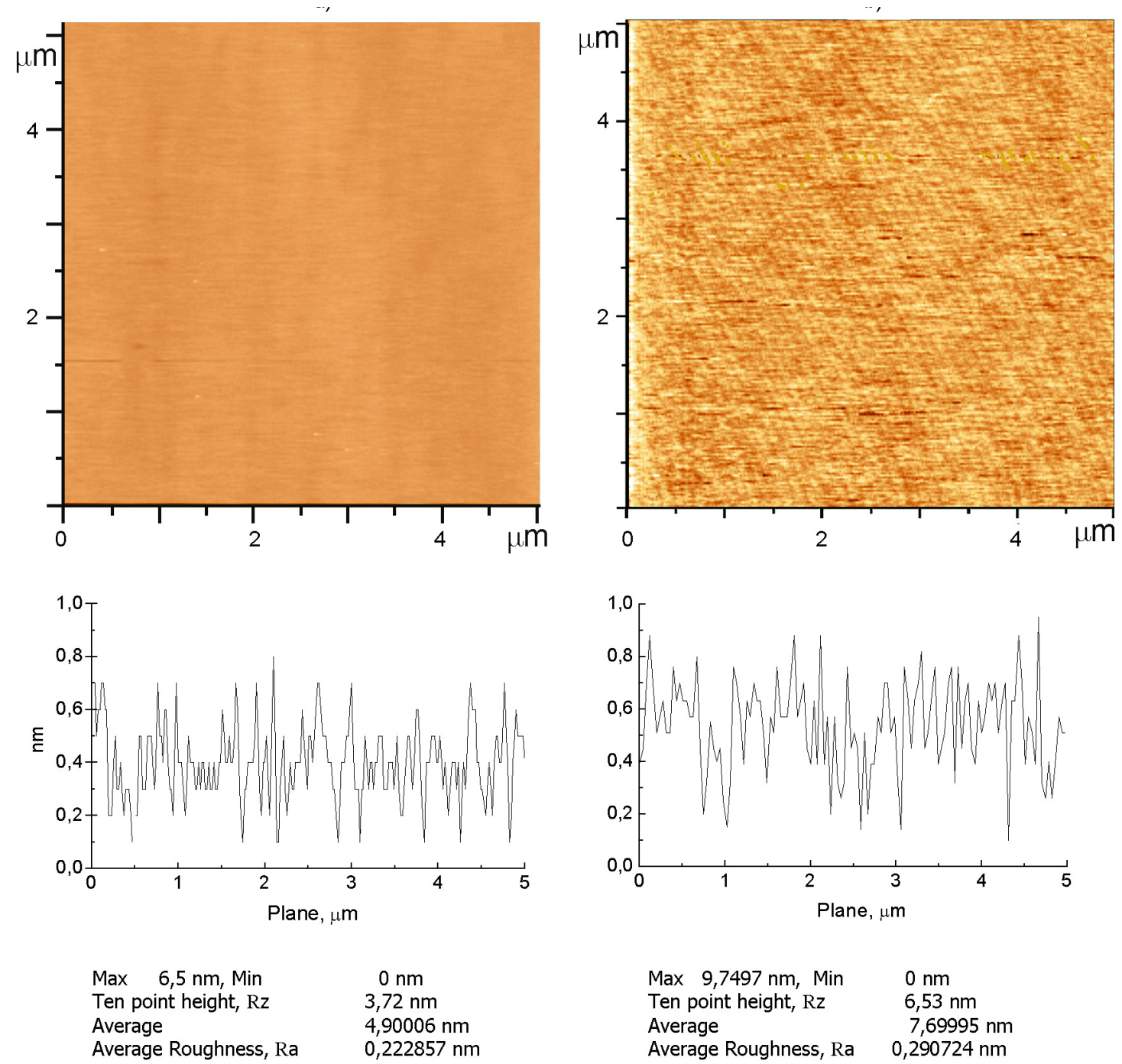

Fig. 5. AFM images and profilograms of the sapphire surface after CMP for crystallographic orientation (a) (10T2), (b) (0001).

resulted in flocculation of $\mathrm{SiO}_{2}$ particles. Viscosity of the suspension decreases with increasing $\mathrm{pH}$. It was established that the optimum conditions of CMP depend on the crystallographic orientation of the sapphire surface. To obtain surface roughness $R_{a}$ $0.2-0.4 \mathrm{~nm}$ for orientation (0001) the polishing preferably have to carried out at $\mathrm{pH}$ 4.5-7.5, for plane (10T2) - at $\mathrm{pH} 6.5-9.5$, and for plane $(1120)-$ at $\mathrm{pH} 7.5-9.5$. The terraced-step surface structure was obtained on the surface with orientation (0001). The quality of the polished surface corresponds to the optical purity class 20/10-40/20 standards USA MIL O 13830.

Acknowledgment. The author expresses his gratitude for the joint research Ph.D. O.M.Vovk (TEM) and Ph.D. S.I.Krivonogov (AFM).

\section{References}

1. SapphireMarketQ42010Update /http://www.imicronews.com/upload/Rapports/Yole Sapphire_Market_Q42010_web.pdf.

2. Sapphire_Market_November_2011_Flyer /http://www.i-micronews.com/upload/Rapports /Yole Sapphire Market November 2011 Flyer. pdf.

3. Handbook of Lapping and Polishing, ed. by I.D.Marinescu, E.Uhlmann,T.Doi, CRC Press Taylor \& Francis Group, London, New York (2015).

4. E.Prochnow, D.F.Edwards, Appl.Optics, 25, 2639 (1986).

5. U.S. Patent 4,806,665 (1989).

6. R.K.Iler, The Chemistry of Silica: Solubility, Polymerization, Colloid and Surface Properties and Biochemistry of Silica, A Wiley-Intersci. Publ., New York-Chichester-Brisbano-Toronto (1979). 
7. J.Eisenlauer, E.Killmann, J.Colloid and Interface Sci., 74, 108 (1980).

8. E.A.Vovk, Functional Materials, 22, 110 (2015).

9. A.T.Budnikov, E.A.Vovk, S.I.Krivonogov et al., Functional Materials, 17, 488 (2010).

10. J.Eisenlauer, E.Killmann, M.Korn, J.Colloid and Interface Sci., 74, 120 (1980).
11. N.A.Shabanova, V.V.Popov, Himiya i Tekhnologiya Nanodispersnyh Oksidov, IKC "Akademkniga", Moscow (2007) [in Russian].

12. F.Cuccureddu, S.Murphy, Shvets et al., Surface Sci., 604, 1294 (2010).

13. A.V.Butashin, V.P.Vlasov, V.M.Kanevskii et al., Crystallogr. Rep., 57, 824 (2012). 